\title{
Primary ovarian ectopic pregnancy: an unusual case study
}

\section{Shikha Sharma, Shelley Moudgil*, Varun Kapoor, Anu Devi}

Department of Obstetrics and Gynecology, Dr. RPGMC Kangra at Tanda, Himachal Pradesh, India

Received: 28 January 2020

Accepted: 28 February 2020

\section{*Correspondence:}

Dr. Shelley Moudgil,

E-mail: shelley1815@gmail.com

Copyright: (C) the author(s), publisher and licensee Medip Academy. This is an open-access article distributed under the terms of the Creative Commons Attribution Non-Commercial License, which permits unrestricted non-commercial use, distribution, and reproduction in any medium, provided the original work is properly cited.

\section{ABSTRACT}

Ovarian pregnancy is rare variant of ectopic pregnancy. An accurate preoperative diagnosis is very challenging various advances in diagnostic modalities like Transvaginal ultrasonography has evolved in identifying an ovarian pregnancy. It results in significant maternal morbidity, fetal loss, repeat ectopic, impairment of subsequent fertility. The case report a 34-year female who presented with pain and severe anemia and explored keeping in view ruptured tubal ectopic but intraoperatively diagnosed as primary ovarian pregnancy and managed conservatively by ovarian wedge resection.

Keywords: Ectopic, Ovarian, Pregnancy

\section{INTRODUCTION}

Ovarian pregnancy is a rare event with incidence between 1 in 2100 to 1 in 7000 pregnancies, or $1-3 \%$ of all ectopic pregnancies. ${ }^{1}$ Ovarian pregnancy is frequently misdiagnosed clinically as a tubal ectopic pregnancy. Intraoperative, it is difficult to differentiate ovarian pregnancy, ruptured corpus luteal cyst or haemorrhagic ovarian cyst. Ovarian pregnancy should satisfy the criteria described by Spigelberg: ${ }^{2}$ (a) intact fallopian tube on the affected side, (b) fetal sac must occupy the position of the ovary on the affected side, (c) ovary connected to the uterus by ovarian ligament, (d) ovarian tissue must be located in the sac wall, to be confirmed by histopathology. There is an obvious need to differentiate between tubal ectopic and ovarian ectopic pregnancies as it will aid in management. ${ }^{3,4}$ Thus, here it lies the necessity of reporting this case.

\section{CASE REPORT}

A total 34 years old G3P2002 reported to labour room with complaint of pain abdomen, generalized weakness and fainting attacks for 3-4 days. On examination patient was conscious, cooperative and well oriented to time place and person. She was pale, her pulse was $128 / \mathrm{min}$, $\mathrm{BP}=90 / 60 \mathrm{mmHg}$. On per abdomen examination there was tenderness in lower abdomen. Per speculum examination cervix and vagina were normal and there was no bleeding, on per vaginum examination cervix was downward forward and cervical motion tenderness was present, uterus was retroverted multiparous size, there was tenderness and fullness in $b / 1$ fornix and POD. Her hemoglobin was $5 \mathrm{gm}$, urine pregnancy test was positive, and paracentesis was also positive, possibility of ruptured ectopic pregnancy was kept. Patient was resuscitated and simultaneously prepared for exploratory laparotomy in view of ruptured ectopic pregnancy. On opening abdomen there was hemoperitoneum of about $800 \mathrm{ml}$ with 200 gm clots. On exploration uterus along with b/1 tubes were grossly normal. Left ovary was enlarged, cystic and g sac like structure was seen, there was a rent on it which was actively bleeding (Figure 1). Wedge resection of left ovary was done and sent for histopathology. Intraoperatively 1 unit of blood was given.

Post operatively 2-unit blood was transfused. Histopathology report came consistent with ovarian pregnancy (Figure 2). Thus, the intraoperative findings 
and the histopathology examination satisfied the criteria for ovarian pregnancy as described by Spigelberg. ${ }^{3}$ The post-operative period was uneventful and patient was discharged successfully on $7^{\text {th }}$ day after skin suture removal.

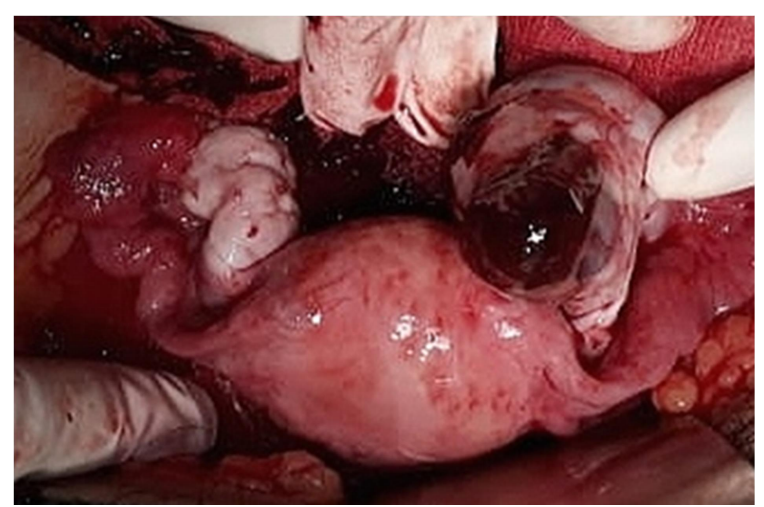

Figure 1: Intraoperative picture of ovarian ectopic pregnancy.

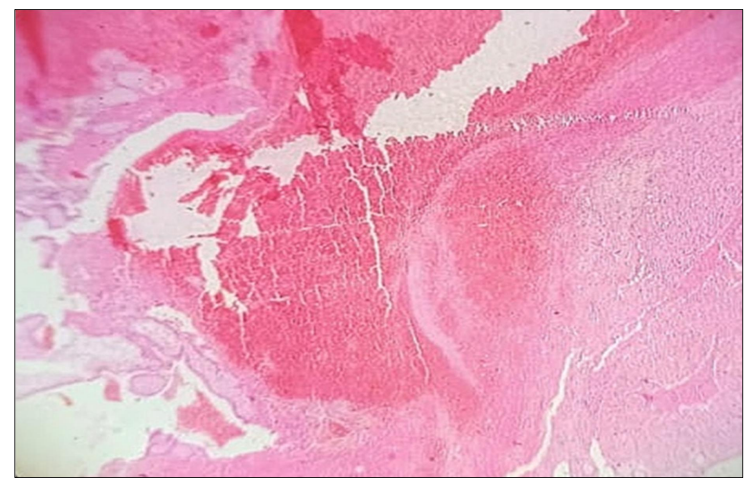

Figure 2: Histopathological picture of ovarian ectopic.

\section{DISCUSSION}

Primary ovarian pregnancy is one of the rarest types of extra-uterine pregnancy. Ectopic pregnancy is the most important cause of maternal death in the first trimester accounting for approximately $10 \%$ of deaths related to pregnancy. Younger age, endometriosis, pelvic inflammatory disease, intra-uterine devices, ovulatory medications, and assisted reproductive techniques are risk factors. ${ }^{5}$ The signs and symptoms of ovarian pregnancy are similar to disturbed tubal pregnancy, conditions most commonly confused with ruptured hemorrhagic corpus luteum and chocolate cyst or tubal ectopic pregnancy. Rupture in the first trimester is the usual rule in an ovarian ectopic. With few exceptions, the initial diagnosis is made on the operating table and the final diagnosis only on histopathology on the basis of the four
Spigelberg criteria, establishing that the pregnancy is limited to the ovary and does not involve the tube. ${ }^{2}$ The etiology of ovarian pregnancy remains unclear, it occurs as a result of a fertilized ovum getting implanted on the ovarian tissue. Out of the modern methods, ultrasonography, laparoscopy and estimation of human chorionic gonadotrophic (hCG) levels have been used in conjunction with repeated clinical evaluation in the diagnosis and management of extra uterine pregnancies. ${ }^{6-}$ ${ }^{8}$ Laparotomy was performed in this case as the patients arrived in hemodynamically unstable condition. The established modes of surgical treatment of ovarian pregnancy are either removal of the entire ovary containing the ectopic gestation or performing a wedge resection of the ovary. Because of viable ovarian tissue of the affected side and young age of the patient, wedge resection with enucleation of the sac was done. Histologically, this case revealed placental and trophoblastic tissue in the ovarian tissue, indicative of the ovarian origin of the ectopic pregnancy. Hence, a diagnosis of primary ovarian pregnancy was made.

Funding: No funding sources

Conflict of interest: None declared

Ethical approval: Not required

\section{REFERENCES}

1. Comstock C, Huston K, Lee W. The ultrasonographic appearance of ovarian ectopic pregnancies. Obstet. Gynecol. 2005;105:42-5.

2. Spigelberg O. Casusistik der ovarial schwan gerschaft. Arch Gynecol. 1878;13:73.

3. Roy J, Sinha Babu A. Ovarian pregnancy: two case reports. AMJ. 2013;6(8):406-10.

4. Nath PK, Panigrahy S, Nath SS, Rout PK, Mohanta C. Primary ovarian ectopic pregnancy: a rare case report. J Evolut Med Dent Sci. 2013;2(48):9339-41.

5. Das S, Kalyani R, Lakshmi V, Kumar MLH. Ovarian pregnancy. Indian J Pathol Microbiol. 2008;51(1):37-8.

6. Bradley WG, Fiske CE, Filly RA. The double sac sign of early intrauterine pregnancy: use in exclusion of ectopic pregnancy. Radiol. 1982;143(1):223-6.

7. Chinn DH, Callen PW. Ultrasound of the acutely ill obstetrics and gynecology patient. Radiol Clin North Am. 1983;21(3):585-94.

8. Lawson TL. Ectopic pregnancy: criteria and accuracy of ultrasonic diagnosis. AJR Am J Roentgenol. 1978;131(1):153-6.

Cite this article as: Sharma S, Moudgil S, Kapoor V, Devi A. Primary ovarian ectopic pregnancy: an unusual case study. Int J Reprod Contracept Obstet Gynecol 2020;9:1741-2. 